This PDF is a selection from a published volume from the National Bureau of Economic Research

Volume Title: Hard-to-Measure Goods and Services: Essays in Honor of Zvi Griliches

Volume Author/Editor: Ernst R. Berndt and Charles R. Hulten, editors

Volume Publisher: University of Chicago Press

Volume ISBN: 0-226-04449-1; 978-0-226-04449-1

Volume URL: http://www.nber.org/books/bern07-1

Conference Date: September 19-20, 2003

Publication Date: October 2007

Title: Information Technology and the G7 Economies

Author: Dale W. Jorgenson

URL: http://www.nber.org/chapters/c0882 


\title{
Information Technology and the G7 Economies
}

\author{
Dale W. Jorgenson
}

\subsection{Introduction}

In this paper I present international comparisons of economic growth among the G7 nations-Canada, France, Germany, Italy, Japan, the United Kingdom, and the United States. These comparisons focus on the impact of investment in information technology (IT) equipment and software over the period 1980 to 2001. In 1998, the G7 nations accounted for nearly 60 percent of world output ${ }^{1}$ and a much larger proportion of world investment in IT. Economic growth in the G7 has experienced a strong revival since 1995, driven by a powerful surge in IT investment.

The resurgence of economic growth in the United States during the 1990 s and the crucial role of IT investment has been thoroughly documented and widely discussed. ${ }^{2}$ Similar trends in the other G7 economies have been more difficult to detect, partly because of discrepancies among official price indexes for IT equipment and software identified by Andrew

Dale W. Jorgenson is the Samuel W. Morris University Professor at Harvard University.

The Economic and Social Research Institute provided financial support from its program on international collaboration through the Nomura Research Institute. I am very grateful to Jon Samuels for excellent research assistance. Alessandra Colecchia, Mun S. Ho, Kazuyuki Motohashi, Koji Nomura, Kevin J. Stiroh, Marcel Timmer, and Bart Van Ark provided valuable data. The Bureau of Economic Analysis and the Bureau of Labor Statistics assisted with data for the United States, and Statistics Canada contributed the data for Canada. I am grateful to all of them but retain sole responsibility for any remaining deficiencies. An earlier version of this paper was published under the same title in World Economics for December 2003.

1. See Angus Maddison (2001) for 1998 data for world GDP and the GDP of each of the G7 countries.

2. See Dale Jorgenson and Kevin Stiroh (2000), Stephen Oliner and Daniel Sichel (2000), and Jorgenson, Ho, and Stiroh (2005). 
Wyckoff (1995). ${ }^{3}$ Paul Schreyer (2000) has constructed "internationally harmonized" IT prices that eliminate many of these discrepancies. ${ }^{4}$

Precise measures of computer prices that hold product quality constant were introduced into the U.S. national accounts in 1985 and the U.S. Producer Price Index (PPI) during the 1990s. The national accounts now rely on PPI data. Gregory Chow (1967) had pioneered the use of hedonic techniques for constructing a constant product quality index of computer prices. Hedonic techniques for modeling automobile prices were introduced by Court (1939) and revived by Zvi Griliches (1961).

The measurement of IT investment reflects steady progress in meeting the challenges arising from hard-to-measure goods and services, but important gaps remain. In addition to the constant quality computer prices introduced in 1985, the U.S. national accounts incorporated constant quality prices for semiconductor products in 1996. Investment in software was first included in the national accounts in the eleventh comprehensive revision, released on October 27, 1999. Research is still underway on constant quality telecommunications equipment prices and constant quality prices for software. ${ }^{5}$

Using internationally harmonized prices for France, Germany, Italy, and the United Kingdom, I have analyzed the role of investment and productivity as sources of growth in the G7 countries over the period 19802001. I have subdivided the period in 1989 and 1995 in order to focus on the most recent experience. I have decomposed growth of output for each country between growth of input and productivity. Finally, I have allocated the growth of input between investments in tangible assets, especially IT and software and human capital. ${ }^{6}$

Growth in IT capital input per capita jumped to double-digit levels in the $\mathrm{G} 7$ nations after 1995. This can be traced to acceleration in the rate of decline of IT prices, analyzed in my presidential address to the American Economic Association. ${ }^{7}$ The powerful surge in investment was most pronounced in Canada, but capital input growth in Japan, the United States, and the United Kingdom was only slightly lower. France, Germany, and Italy also experienced double-digit growth, but lagged considerably behind the leaders.

During the 1980s, productivity played a minor role as a source of growth for the G7 countries except Japan, where productivity accounted for 30 percent of economic growth. Productivity accounted for only 15 percent of

3. See Wyckoff (1995).

4. See Schreyer (2000). Colecchia and Schreyer (2002) have employed these internationally harmonized prices in measuring the impact of IT investment.

5. Further details are provided by Jorgenson, Ho, and Stiroh (2005).

6. Methods for productivity measurement are presented in detail by Jorgenson, Ho, and Stiroh (2005). A more concise exposition is provided by Jorgenson (2005).

7. See Jorgenson (2001). 
growth in the United States, 13 percent in France and the United Kingdom, and 12 percent in Germany; only 2 percent of growth in Canada was due to productivity, while the decline of productivity retarded growth by 14 percent in Italy. Between 1989 and 1995, productivity growth declined further in the G7 nations, except for Italy and Germany. Productivity declined for France and the United Kingdom but remained positive for the United States, Canada, and Japan.

Productivity growth revived in all the G7 countries after 1995, again with the exception of Germany and Italy. The resurgence was most dramatic in Canada, the United Kingdom, and France, partly offsetting years of dismal productivity growth. Japan exhibited the highest growth in output per capita among the G7 nations from 1980 to 1995. Japan's level of output per capita rose from the lowest in the $\mathrm{G} 7$ to the middle of the group in 2001. Although this advance owed more to input per capita than productivity, Japan's productivity growth far outstripped the other members of the G7. Nonetheless, Japan's productivity remained the lowest among the $\mathrm{G} 7$ nations.

The United States led the G7 in output per capita for the period 1989 to 2001. Canada's edge in output per capita in 1980 had disappeared by 1989. The United States led the G7 countries in input per capita during 1980 to 2001, but U.S. productivity languished below the levels of Canada, France, and Italy.

In section 11.2, I outline the methodology for this study, based on my presidential address. I have revised and updated the U.S. data presented there through 2001. Comparable data on investment in IT have been constructed for Canada by Statistics Canada. ${ }^{8}$ Data on IT for France, Germany, Italy, and the United Kingdom have been developed for the European Commission by Bart van Ark et al. (2002). ${ }^{9}$ Finally, data for Japan have been assembled by myself and Kazuyuki Motohashi for the Research Institute on Economy, Trade, and Industry. ${ }^{10} \mathrm{I}$ have linked these data by means of the Organization for Economic Cooperation and Development's (OECD's) purchasing power parities for 1999. ${ }^{11}$

In section 11.3, I consider the impact of IT investment and the relative importance of investment and productivity in accounting for economic growth among the G7 nations. Investments in human capital and tangible assets, especially IT equipment and software, account for the overwhelming proportion of growth. Differences in the composition of capital and labor inputs are essential for identifying persistent international differences in output and accounting for the impact of IT investment.

8. See John Baldwin and Tarek Harchaoui (2002).

9. See van Ark et al. (2002).

10. See Jorgenson and Motohashi (2005).

11. See OECD (2002). Current data on purchasing power parities are available from the OECD Web site: http://www.sourceoecd.org. 
In section 11.4, I consider alternative approaches to international comparisons. The great revival of interest in economic growth among economists dates from Maddison's (1982) updating and extension of Simon Kuznets's (1971) long-term estimates of the growth of national product and population for fourteen industrialized countries, including the $\mathrm{G} 7$ nations. Maddison $(1982,1991)$ added Austria and Finland to Kuznets' list and presented growth rates covering periods beginning as early as 1820 and extending through 1989.

Maddison $(1987,1991)$ also generated growth accounts for major industrialized countries, but did not make level comparisons like those presented in section 11.2. As a consequence, productivity differences were omitted from the canonical formulation of "growth regressions" by William Baumol (1986). This proved to be a fatal flaw in Baumol's regression model, remedied by Nazrul Islam's (1995) panel data model. Section 11.5 concludes the paper.

\subsection{Investment and Productivity}

My papers with Laurits Christensen and Dianne Cummings (Christensen, Cummings, and Jorgenson 1980, 1981) developed growth accounts for the United States and its major trading partners-Canada, France, Germany, Italy, Japan, Korea, the Netherlands, and the United Kingdom for 1947 to 1973. We employed gross national product (GNP) as a measure of output and incorporated constant quality indexes of capital and labor input for each country. Our 1981 paper compared levels of output, inputs, and productivity for all nine nations.

I have updated the estimates for the G7-Canada, France, Germany, Italy, Japan, the United Kingdom, and the United States - through 1995 in earlier work. The updated estimates are presented in my papers with Chrys Dougherty (Dougherty and Jorgenson 1996, 1997) and Eric Yip (Jorgenson and Yip 2000). We have shown that productivity accounted for only 11 percent of economic growth in Canada and the United States over the period 1960 to 1995.

My paper with Yip (Jorgenson and Yip 2000) attributed 47 percent of Japanese economic growth during the period 1960-1995 to productivity growth. The proportion attributable to productivity approximated 40 percent of growth for the four European countries-France (.38), Germany (.42), Italy (.43), and the United Kingdom (.36). Input growth predominated over productivity growth for all the $\mathrm{G} 7$ nations.

I have now incorporated new data on investment in IT equipment and software for the G7. I have also employed internationally harmonized prices like those constructed by Schreyer (2000). As a consequence, I have been able to separate the contribution of capital input to economic growth into IT and non-IT components. While IT investment follows similar pat- 
terns in all the G7 nations, non-IT investment varies considerably and helps to explain important differences in growth rates among the G7.

\subsubsection{Comparisons of Output, Input, and Productivity}

My first objective is to extend my estimates for the G7 nations with Christensen, Cummings, Dougherty, and Yip to the year 2001. Following the methodology originally proposed by Jorgenson and Griliches (1967), I have chosen gross domestic product (GDP) as a measure of output. I have included imputations for the services of consumers' durables as well as land, buildings, and equipment owned by nonprofit institutions. I have also distinguished between investments in IT equipment and software and investments in other forms of tangible assets.

A constant quality index of capital input is based on weights that reflect differences in capital consumption, tax treatment, and the rate of decline of asset prices. I have derived estimates of capital input and property income from national accounting data. Similarly, a constant quality index of labor input is based on weights by age, sex, educational attainment, and employment status. I have constructed estimates of hours worked and labor compensation from labor force surveys for each country.

In table 11.1, I present output per capita for the G7 nations from 1980 to 2001, taking the United States as 100.0 in 2000. Output and population are given separately in tables 11.2 and 11.3. I use 1999 purchasing power parities from the OECD to convert output from domestic prices for each country into U.S. dollars. The United States maintained its lead among the G7

Table 11.1

Levels of output and input per capita and total factor productivity

\begin{tabular}{|c|c|c|c|c|c|c|c|}
\hline Year & $\begin{array}{l}\text { United } \\
\text { States }\end{array}$ & Canada & $\begin{array}{c}\text { United } \\
\text { Kingdom }\end{array}$ & France & Germany & Italy & Japan \\
\hline \multicolumn{8}{|c|}{ Output per capita } \\
\hline 1980 & 63.9 & 67.6 & 45.0 & 45.9 & 49.3 & 45.9 & 43.6 \\
\hline 1989 & 79.7 & 78.8 & 56.5 & 54.1 & 58.6 & 57.3 & 58.4 \\
\hline 1995 & 85.6 & 79.6 & 61.4 & 57.0 & 65.0 & 62.1 & 65.4 \\
\hline 2001 & 100.3 & 91.9 & 71.3 & 64.0 & 69.2 & 68.8 & 70.4 \\
\hline \multicolumn{8}{|c|}{ Input per capita } \\
\hline 1980 & 70.5 & 64.2 & 50.2 & 46.5 & 61.0 & 43.1 & 61.9 \\
\hline 1989 & 83.9 & 74.4 & 61.2 & 53.3 & 71.1 & 55.5 & 74.8 \\
\hline 1995 & 88.8 & 75.2 & 67.0 & 57.0 & 73.7 & 58.8 & 78.8 \\
\hline 2001 & 100.8 & 83.7 & 73.6 & 61.7 & 79.0 & 67.2 & 81.1 \\
\hline \multicolumn{8}{|c|}{ Total factor productivity } \\
\hline 1980 & 90.6 & 105.4 & 89.5 & 98.6 & 80.8 & 106.6 & 70.4 \\
\hline 1989 & 94.9 & 105.9 & 92.3 & 101.5 & 82.4 & 103.2 & 78.0 \\
\hline 1995 & 96.4 & 105.9 & 91.7 & 99.9 & 88.1 & 105.6 & 83.0 \\
\hline 2001 & 99.5 & 109.7 & 96.9 & 103.6 & 87.6 & 102.5 & 86.8 \\
\hline
\end{tabular}

Notes: U.S. $=100.0$ in 2000. Canada data begins in 1981. 
Table 11.2

Growth rate and level of output

\begin{tabular}{|c|c|c|c|c|c|c|c|}
\hline Year & $\begin{array}{l}\text { United } \\
\text { States }\end{array}$ & Canada & $\begin{array}{c}\text { United } \\
\text { Kingdom }\end{array}$ & France & Germany & Italy & Japan \\
\hline \multicolumn{8}{|c|}{ Growth rate (\%) } \\
\hline 1980-1989 & 3.38 & 3.10 & 2.69 & 2.38 & 1.99 & 2.51 & 3.83 \\
\hline 1989-1995 & 2.43 & 1.39 & 1.62 & 1.30 & 2.34 & 1.52 & 2.23 \\
\hline $1995-2001$ & 3.76 & 3.34 & 2.74 & 2.34 & 1.18 & 1.90 & 1.45 \\
\hline \multicolumn{8}{|c|}{ Level (billions of 2000 U.S. dollars) } \\
\hline 1980 & $5,361.2$ & 618.4 & 934.0 & 932.0 & $1,421.7$ & 955.7 & $1,875.9$ \\
\hline 1989 & $7,264.2$ & 792.6 & $1,190.3$ & $1,154.3$ & $1,700.2$ & $1,197.4$ & $2,648.7$ \\
\hline 1995 & $8,403.3$ & 861.4 & $1,311.8$ & $1,247.8$ & $1,956.3$ & $1,311.5$ & $3,017.1$ \\
\hline 2001 & $10,530.4$ & $1,052.3$ & $1,545.9$ & $1,436.0$ & $2,099.8$ & $1,470.1$ & $3,301.3$ \\
\hline \multicolumn{8}{|c|}{ Level $($ U.S. $=100.0$ in 2000$)$} \\
\hline 1980 & 51.6 & 5.9 & 9.0 & 9.0 & 13.7 & 9.2 & 18.0 \\
\hline 1989 & 69.9 & 7.6 & 11.4 & 11.1 & 16.3 & 11.5 & 25.5 \\
\hline 1995 & 80.8 & 8.3 & 12.6 & 12.0 & 18.8 & 12.6 & 29.1 \\
\hline 2001 & 101.3 & 10.1 & 14.9 & 13.8 & 20.2 & 14.1 & 31.7 \\
\hline
\end{tabular}

Note: Canada data begins in 1981.

Table 11.3 Growth rate and level in population (\%)

\begin{tabular}{|c|c|c|c|c|c|c|c|}
\hline Year & $\begin{array}{l}\text { United } \\
\text { States }\end{array}$ & Canada & $\begin{array}{c}\text { United } \\
\text { Kingdom }\end{array}$ & France & Germany & Italy & Japan \\
\hline \multicolumn{8}{|c|}{ Growth rate } \\
\hline 1980-1989 & 0.92 & 1.18 & 0.16 & 0.54 & 0.05 & 0.05 & 0.59 \\
\hline 1989-1995 & 1.23 & 1.22 & 0.24 & 0.45 & 0.62 & 0.18 & 0.33 \\
\hline 1995-2001 & 1.12 & 0.95 & 0.24 & 0.41 & 0.14 & 0.18 & 0.22 \\
\hline \multicolumn{8}{|c|}{ Level (millions) } \\
\hline 1980 & 227.7 & 24.8 & 56.3 & 55.1 & 78.3 & 56.4 & 116.8 \\
\hline 1989 & 247.4 & 27.3 & 57.1 & 57.9 & 78.7 & 56.7 & 123.1 \\
\hline 1995 & 266.3 & 29.4 & 58.0 & 59.4 & 81.7 & 57.3 & 125.6 \\
\hline 2001 & 284.8 & 31.1 & 58.8 & 60.9 & 82.3 & 57.9 & 127.2 \\
\hline \multicolumn{8}{|c|}{ Level $($ US. $=100.0$ in 2000$)$} \\
\hline 1980 & 80.7 & 8.8 & 20.0 & 19.5 & 27.8 & 20.0 & 41.4 \\
\hline 1989 & 87.7 & 9.7 & 20.3 & 20.5 & 27.9 & 20.1 & 43.6 \\
\hline 1995 & 94.4 & 10.4 & 20.5 & 21.1 & 28.9 & 20.3 & 44.5 \\
\hline 2001 & 101.0 & 11.0 & 20.8 & 21.6 & 29.2 & 20.5 & 45.1 \\
\hline
\end{tabular}

Note: Canada data begins in 1981.

countries in output per capita after 1989. Canada led the United States in 1980 , but fell behind during the 1980s. The U.S.-Canada gap widened considerably during the 1990s.

The four major European nations - the United Kingdom, France, Germany, and Italy — had very similar levels of output per capita throughout the period 1980-2001. Japan rose from last place in 1980 to fourth among 


\begin{tabular}{lccccccc}
\hline Year & $\begin{array}{c}\text { United } \\
\text { States }\end{array}$ & Canada & $\begin{array}{c}\text { United } \\
\text { Kingdom }\end{array}$ & France & Germany & Italy & Japan \\
\hline \multicolumn{7}{c}{ Output per capita } \\
$1980-1989$ & 2.46 & 1.92 & 2.54 & 1.84 & 1.93 & 2.46 & 3.25 \\
$1989-1995$ & 1.20 & 0.17 & 1.38 & 0.85 & 1.72 & 1.33 & 1.90 \\
$1995-2001$ & 2.64 & 2.38 & 2.50 & 1.93 & 1.04 & 1.72 & 1.23 \\
& \multicolumn{7}{c}{ Input per capita } \\
$1980-1989$ & 1.94 & 1.86 & 2.20 & 1.52 & 1.71 & 2.82 & 2.10 \\
$1989-1995$ & 0.94 & 0.17 & 1.49 & 1.11 & 0.60 & 0.96 & 0.86 \\
$1995-2001$ & 2.10 & 1.80 & 1.59 & 1.33 & 1.14 & 2.21 & 0.48 \\
& & \multicolumn{7}{c}{ Total factor productivity } \\
$1980-1989$ & 0.52 & 0.06 & 0.34 & 0.32 & 0.23 & -0.36 & 1.15 \\
$1989-1995$ & 0.26 & 0.00 & -0.11 & -0.26 & 1.12 & 0.37 & 1.04 \\
$1995-2001$ & 0.54 & 0.58 & 0.91 & 0.60 & -0.10 & -0.49 & 0.75 \\
\hline
\end{tabular}

Note: Canada data begins in 1981.

the G7 in 2001, lagging considerably behind the United States and Canada, but only slightly behind the United Kingdom. Japan led the G7 in the growth of output per capita from 1980 to 1995, but fell behind the United States, Canada, the United Kingdom, France, and Italy after 1995.

In table 11.1, I present input per capita for the G7 over the period 1980 to 2001, taking the United States as 100.0 in 2000. I express input per capita in U.S. dollars, using purchasing power parities constructed for this study. ${ }^{12}$ The United States was the leader among the G7 in input per capita throughout the period. In 2001, Canada ranked next to the United States, with Japan third and Germany fourth. France and Italy started at the bottom of the ranking and remained there throughout the period.

In table 11.1, I also present productivity levels for the $\mathrm{G} 7$ over the period 1980 to 2001. Productivity is defined as the ratio of output to input, including both capital and labor inputs. Canada was the productivity leader during the period 1989 to 2001, with France and Italy close behind, despite the drop in productivity in Italy! Japan made the most substantial gains in productivity, while there were more modest increases in the United States, Canada, the United Kingdom, France, and Germany.

I summarize growth in output and input per capita and productivity for the $\mathrm{G} 7$ nations in table 11.4. I present growth rates of output and population for the period 1980 to 2001 in tables 11.2 and 11.3. Output growth slowed in the G7 after 1989 but revived for all nations except Japan and

12. The purchasing power parities for outputs are based on OECD (2002). Purchasing power parities for inputs follow the methodology described in detail by Jorgenson and Yip (2001). 
Germany after 1995. Output per capita followed a similar pattern, with Canada barely expanding during the period 1989 to 1995.

Japan led in growth of output per capita through 1995, but fell to the lower echelon of the G7 after 1995. Japan led in productivity growth during 1980 to 1989, Germany led from 1989 to 1995, and the United Kingdom led from 1995 to 2001. For all countries and all time periods, except for Germany during the period 1989 to 1995 and Japan after 1989, the growth of input per capita exceeded growth of productivity by a substantial margin. Productivity growth in the G7 slowed during the period 1989 to 1995 , except for Germany and Italy, where productivity slumped after 1995.

Italy led the G7 in growth of input per capita for the periods 1980 to 1989 and 1995 to 2001, but relinquished leadership to the United Kingdom for the period 1989 to 1995. Differences among input growth rates are smaller than differences among output growth rates, but there was a slowdown in input growth during 1989 to 1995 throughout the G7. After 1995 growth of input per capita increased in every G7 nation except Japan.

\subsubsection{Comparisons of Capital and Labor Quality}

A constant quality index of capital input weights capital inputs by property compensation per unit of capital. By contrast, an index of capital stock weights different types of capital by asset prices. The ratio of capital input to capital stock measures the average quality of a unit of capital. This represents the difference between the constant quality index of capital input introduced by Jorgenson and Griliches (1967) and the index of capital stock employed, for example, by Kuznets (1971) and Robert Solow (1970).

In table 11.5, I present capital input per capita for the G7 countries over the period 1980 to 2001 relative to the United States in 2000. The United States was the leader in capital input per capita throughout the period, while Japan was the laggard. Canada led the remaining six countries in 1980, but was overtaken by Germany and Italy in 1995. Italy led the rest of the G7 through 2001, but lagged considerably behind the United States.

The picture for capital stock per capita has some similarities to capital input, but there are important differences. Capital stock levels do not accurately reflect the substitutions among capital inputs that accompany investments in tangible assets, especially investments in IT equipment and software. Japan led the G7 in capital stock per capita throughout the period 1980 to 2001. The United Kingdom lagged the remaining countries of the $\mathrm{G} 7$ throughout the period.

The behavior of capital quality highlights the differences between the constant quality index of capital input and capital stock. There are important changes in capital quality over time and persistent differences among countries so that heterogeneity in capital input must be taken into account in international comparisons of economic performance. Canada was the 
Table 11.5

\begin{tabular}{|c|c|c|c|c|c|c|c|}
\hline Year & $\begin{array}{l}\text { United } \\
\text { States }\end{array}$ & Canada & $\begin{array}{l}\text { United } \\
\text { Kingdom }\end{array}$ & France & Germany & Italy & Japan \\
\hline \multicolumn{8}{|c|}{ Capital input per capita } \\
\hline 1980 & 57.7 & 56.0 & 25.8 & 36.3 & 44.6 & 35.6 & 32.8 \\
\hline 1989 & 73.7 & 67.1 & 37.9 & 48.3 & 62.1 & 62.4 & 43.5 \\
\hline 1995 & 81.6 & 68.3 & 50.0 & 52.7 & 72.3 & 73.1 & 50.7 \\
\hline 2001 & 103.9 & 78.0 & 56.1 & 58.1 & 83.5 & 89.4 & 58.3 \\
\hline \multicolumn{8}{|c|}{ Capital stock per capita } \\
\hline 1980 & 76.8 & 40.7 & 24.1 & 36.2 & 60.2 & 36.0 & 93.1 \\
\hline 1989 & 88.4 & 48.5 & 31.2 & 42.4 & 67.9 & 52.4 & 104.1 \\
\hline 1995 & 92.2 & 50.8 & 35.9 & 47.0 & 77.0 & 62.3 & 114.8 \\
\hline 2001 & 101.7 & 55.1 & 44.5 & 52.0 & 85.5 & 72.3 & 122.2 \\
\hline \multicolumn{8}{|c|}{ Capital quality } \\
\hline 1980 & 75.1 & 137.5 & 107.0 & 100.1 & 74.0 & 98.8 & 35.2 \\
\hline 1989 & 83.4 & 138.2 & 121.7 & 114.0 & 91.5 & 119.1 & 41.8 \\
\hline 1995 & 88.5 & 134.6 & 139.3 & 112.2 & 94.0 & 117.4 & 44.2 \\
\hline 2001 & 102.2 & 141.5 & 126.1 & 111.9 & 97.7 & 123.6 & 47.7 \\
\hline
\end{tabular}

Notes: U.S. $=100.0$ in 2000. Canada data begins in 1981 .

Table 11.6

Growth in capital input and capital stock per capita and capital quality (\%)

\begin{tabular}{lccccccc}
\hline Year & $\begin{array}{c}\text { United } \\
\text { States }\end{array}$ & Canada & $\begin{array}{c}\text { United } \\
\text { Kingdom }\end{array}$ & France & Germany & Italy & Japan \\
\hline 1980-1989 & 2.72 & 2.26 & 4.28 & 3.19 & 3.70 & 6.25 & 3.16 \\
$1989-1995$ & 1.70 & 0.31 & 4.61 & 1.46 & 2.53 & 2.63 & 2.55 \\
$1995-2001$ & 4.03 & 2.20 & 1.92 & 1.63 & 2.40 & 3.35 & 2.31 \\
& & \multicolumn{7}{c}{ Capital input per capita } \\
$1980-1989$ & 1.56 & 2.19 & 2.85 & 1.74 & 1.34 & 4.18 & 1.25 \\
$1989-1995$ & 0.70 & 1.05 & 2.36 & 1.74 & 2.09 & 2.87 & 1.63 \\
$1995-2001$ & 1.63 & 1.36 & 3.57 & 1.67 & 1.75 & 2.49 & 1.04 \\
& & \multicolumn{7}{c}{ Capital stock per capita } & & & \\
$1980-1989$ & 1.17 & 0.07 & 1.43 & 1.45 & 2.36 & 2.07 & 1.91 \\
$1989-1995$ & 0.99 & -0.74 & 2.25 & -0.27 & 0.44 & -0.24 & 0.92 \\
$1995-2001$ & 2.40 & 0.84 & -1.65 & -0.04 & 0.65 & 0.86 & 1.26 \\
\hline
\end{tabular}

Note: Canada data begins in 1981.

international leader in capital quality in 1980 and 2001, relinquishing the lead to the United Kingdom in 1995, while Japan ranked at the bottom of the $\mathrm{G} 7$ throughout the period.

I summarize growth in capital input and capital stock per capita as well as capital quality for the G7 nations in table 11.6. Italy was the international leader in capital input growth from 1980 to 1989, while the Canada 
was the laggard. The United Kingdom led from 1989 to 1995, while Canada lagged considerably behind the rest of the G7. The United States took the lead after 1995. There was a slowdown in capital input growth throughout the G7 after 1989, except for the United Kingdom, and a revival after 1995 in the United States, Canada, France, and Italy.

A constant quality index of labor input weights hours worked for different categories by labor compensation per hour. An index of hours worked fails to take quality differences into account. The ratio of labor input to hours worked measures the average quality of an hour of labor, as reflected in its marginal product. This represents the difference between the constant quality index of labor input used by Jorgenson and Griliches (1967) and the index of hours worked employed, for example, by Kuznets (1971) and Solow (1970).

In table 11.7, I present labor input per capita for the $\mathrm{G} 7$ nations for the period 1980 to 2001 relative to the United States in 2000. Japan was the international leader throughout the period 1980 to 2001. Labor input in Japan was nearly double that in Italy. The United States led the remaining G7 nations. The United Kingdom ranked third among the G7 through 1995, but fell slightly behind Canada in 2001. Italy and France lagged behind the rest of the $\mathrm{G} 7$ for the entire period.

The picture for hours worked per capita has some similarities to labor input, but there are important differences. Japan was the international leader

Table 11.7 Levels of labor input and hours worked per capita and labor quality

\begin{tabular}{|c|c|c|c|c|c|c|c|}
\hline Year & $\begin{array}{l}\text { United } \\
\text { States }\end{array}$ & Canada & $\begin{array}{c}\text { United } \\
\text { Kingdom }\end{array}$ & France & Germany & Italy & Japan \\
\hline \multicolumn{8}{|c|}{ Labor input per capita } \\
\hline 1980 & 81.1 & 73.0 & 78.9 & 63.0 & 75.4 & 48.8 & 94.8 \\
\hline 1989 & 91.9 & 82.1 & 85.4 & 59.4 & 78.7 & 51.0 & 107.5 \\
\hline 1995 & 94.2 & 82.3 & 82.4 & 61.7 & 75.2 & 50.6 & 105.5 \\
\hline 2001 & 98.8 & 89.3 & 89.2 & 65.3 & 75.9 & 55.1 & 100.9 \\
\hline \multicolumn{8}{|c|}{ Hours worked per capita } \\
\hline 1980 & 89.7 & 91.4 & 92.0 & 79.3 & 82.3 & 71.4 & 111.9 \\
\hline 1989 & 97.1 & 96.6 & 97.7 & 71.2 & 82.7 & 72.1 & 115.6 \\
\hline 1995 & 95.9 & 90.9 & 89.8 & 67.6 & 76.4 & 68.9 & 109.9 \\
\hline 2001 & 98.3 & 96.3 & 94.2 & 69.7 & 75.3 & 72.3 & 101.1 \\
\hline \multicolumn{8}{|c|}{ Labor quality } \\
\hline 1980 & 90.4 & 79.9 & 85.7 & 79.5 & 91.6 & 68.3 & 84.7 \\
\hline 1989 & 94.7 & 85.0 & 87.4 & 83.5 & 95.2 & 70.7 & 93.0 \\
\hline 1995 & 98.2 & 90.6 & 91.7 & 91.2 & 98.4 & 73.5 & 96.0 \\
\hline 2001 & 100.5 & 92.7 & 94.7 & 93.7 & 100.9 & 76.1 & 99.9 \\
\hline
\end{tabular}

Notes: U.S. $=100.0$ in 2000. Canada data begins in 1981. 
in hours worked per capita. The United States, Canada, and the United Kingdom moved roughly in parallel. The United Kingdom ranked second in 1980 and 1989, while the United States ranked second in 1995 and 2001. France and Italy lagged the rest of the G7 from 1980 to 2001.

The behavior of labor quality highlights the differences between labor input and hours worked. Germany was the leader in labor quality throughout the period 1980 to 2001 . The United States ranked second in labor quality, but Canada, France, the United Kingdom, and Japan approached U.S. levels in 2001. Labor quality levels in these four countries moved in parallel throughout the period. Italy was the laggard among the G7 in labor quality as well as hours worked.

I summarize growth in labor input and hours worked per capita as well as labor quality for the period 1980 to 2001 in table 11.8. Canada and Japan led the G7 nations in labor input growth during the 1980s, France led from 1989 to 1995 but relinquished its leadership to Italy after 1995. Labor input growth was negative for France during the 1980s, for the United Kingdom, Germany, Italy, and Japan during the period 1989 to 1995, and for Japan after 1995.

Hours worked per capita fell continuously through the 1989 to 2001 period for Japan and declined for all the G7 nations during the period 1989 to 1995 . Growth in labor quality was positive for the $\mathrm{G} 7$ nations in all time periods. Japan was the leader during the 1980s, relinquishing its lead to France during the early 1990s, but regaining its lead in the 1995 to 2001 period. Growth in labor quality and hours worked are equally important as sources of growth in labor input for the G7.

Table 11.8

Growth in labor input and hours worked per capita and labor quality (\%)

\begin{tabular}{|c|c|c|c|c|c|c|c|}
\hline Year & $\begin{array}{l}\text { United } \\
\text { States }\end{array}$ & Canada & $\begin{array}{c}\text { United } \\
\text { Kingdom }\end{array}$ & France & Germany & Italy & Japan \\
\hline \multicolumn{8}{|c|}{ Labor input per capita } \\
\hline 1980-1989 & 1.38 & 1.47 & 0.88 & -0.65 & 0.48 & 0.49 & 1.40 \\
\hline 1989-1995 & 0.41 & 0.04 & -0.59 & 0.61 & -0.78 & -0.13 & -0.32 \\
\hline $1995-2001$ & 0.79 & 1.35 & 1.32 & 0.95 & 0.17 & 1.40 & -0.73 \\
\hline \multicolumn{8}{|c|}{ Hours worked per capita } \\
\hline 1980-1989 & 0.87 & 0.69 & 0.67 & -1.20 & 0.06 & 0.10 & 0.36 \\
\hline 1989-1995 & -0.21 & -1.02 & -1.41 & -0.86 & -1.33 & -0.75 & -0.84 \\
\hline $1995-2001$ & 0.41 & 0.98 & 0.79 & 0.50 & -0.25 & 0.81 & -1.39 \\
\hline \multicolumn{8}{|c|}{ Labor quality } \\
\hline 1980-1989 & 0.51 & 0.78 & 0.21 & 0.55 & 0.42 & 0.39 & 1.04 \\
\hline 1989-1995 & 0.61 & 1.06 & 0.81 & 1.47 & 0.55 & 0.63 & 0.52 \\
\hline 1995-2001 & 0.38 & 0.38 & 0.53 & 0.45 & 0.41 & 0.60 & 0.66 \\
\hline
\end{tabular}

Note: Canada data begins in 1981. 


\subsection{Investment in IT}

Using data from tables 11.1 and 11.2, I can assess the relative importance of investment and productivity as sources of economic growth for the G7 nations. Investments in tangible assets and human capital greatly predominated over productivity during the period 1980 to 2001 . While productivity fell in Italy during this period, the remaining G7 countries had positive productivity growth.

Similarly, using data from table 11.5, I can assess the relative importance of growth in capital stock and capital quality. Capital input growth was positive for all countries for the period 1980 to 2001 and all three subperiods. Capital quality growth was positive for the period as a whole for all G7 countries. Although capital stock predominated in capital input growth, capital quality was also quantitatively significant, especially after 1995.

Finally, using data from table 11.7, I can assess the relative importance of growth in hours worked and labor quality. Hours worked per capita declined for France, Germany, and Japan, while labor quality rose in these nations during the period 1980 to 2001. For the United States, Canada, the United Kingdom, and Italy, both hours worked per capita and labor quality rose. I conclude that labor quality growth is essential to the analysis of growth in labor input.

\subsubsection{Investment in IT Equipment and Software}

The final step in the comparison of patterns of economic growth among the G7 nations is to analyze the impact of investment in IT equipment and software. In table 11.9, I present levels of IT capital input per capita for the G7 for the period 1980 to 2001, relative to the United States in 2000. The United States overtook Germany in 1989 and remained the leader through 2001. Canada lagged behind the rest of the G7 through 1995, but France fell into last place in 2001.

Table 11.9 reveals substantial differences between IT capital stock and IT capital input. The G7 nations began with very modest stocks of IT equipment and software per capita in 1980. These stocks expanded rapidly during the period 1980 to 2001. The United States led in IT capital stock throughout the period, while Japan moved from the fourth highest level in 1980 to the third highest in 2001.

IT capital quality reflects differences in the composition of IT capital input, relative to IT capital stock. A rising level of capital quality indicates a shift toward short-lived assets, such as computers and software. This shift is particularly dramatic for the United States, Canada, and Japan, while the composition of IT capital stock changed relatively less for the United Kingdom, France, Germany, and Italy. Patterns for non-IT capital input, capital stock, and capital quality largely reflect those for capital as a whole, presented in table 11.10. 
Table 11.9

Levels of IT capital input and IT capital stock per capita and IT capital quality

\begin{tabular}{rrrrrrrr}
\hline Year & $\begin{array}{c}\text { United } \\
\text { States }\end{array}$ & Canada & $\begin{array}{c}\text { United } \\
\text { Kingdom }\end{array}$ & France & Germany & Italy & Japan \\
\hline \multicolumn{7}{c}{ IT capital input per capita } \\
1980 & 4.5 & 1.0 & 3.0 & 4.2 & 7.1 & 6.7 & 1.7 \\
1989 & 19.3 & 3.9 & 10.9 & 11.9 & 18.7 & 18.8 & 10.3 \\
1995 & 38.1 & 11.2 & 20.9 & 19.1 & 31.1 & 31.2 & 19.0 \\
2001 & 115.3 & 45.6 & 53.6 & 38.1 & 59.7 & 60.3 & 46.0 \\
& & \multicolumn{7}{c}{ IT capital stock per capita } & & & \\
1980 & 9.8 & 0.8 & 2.5 & 3.5 & 6.1 & 4.6 & 3.5 \\
1989 & 27.4 & 3.7 & 9.6 & 9.9 & 15.5 & 13.1 & 12.7 \\
1995 & 46.8 & 9.7 & 19.2 & 18.0 & 28.2 & 23.8 & 22.9 \\
2001 & 110.7 & 31.8 & 44.9 & 33.4 & 49.7 & 44.1 & 47.8 \\
& & \multicolumn{7}{c}{ IT capital quality } & & & \\
1980 & 46.4 & 118.4 & 118.5 & 117.5 & 117.4 & 146.8 & 47.8 \\
1989 & 70.4 & 107.4 & 112.7 & 119.7 & 120.4 & 143.2 & 81.1 \\
1995 & 81.3 & 115.0 & 108.9 & 106.2 & 110.1 & 131.0 & 83.0 \\
2001 & 104.1 & 143.4 & 119.3 & 114.1 & 120.2 & 136.6 & 96.1 \\
\hline
\end{tabular}

Notes: U.S. $=100.0$ in 2000. Canada data begins in 1981.

Table 11.10 Levels of non-IT capital input and capital stock per capita and non-IT capital quality

\begin{tabular}{rrrrrrrr}
\hline Year & $\begin{array}{c}\text { United } \\
\text { States }\end{array}$ & Canada & $\begin{array}{c}\text { United } \\
\text { Kingdom }\end{array}$ & France & Germany & Italy & Japan \\
\hline \multicolumn{7}{c}{ Non-IT capital input per capita } \\
1980 & 73.8 & 73.1 & 30.7 & 41.3 & 51.9 & 41.6 & 39.3 \\
1989 & 87.0 & 83.1 & 43.4 & 53.9 & 70.3 & 71.3 & 47.9 \\
1995 & 90.7 & 79.9 & 55.9 & 57.9 & 79.7 & 81.2 & 53.9 \\
2001 & 102.2 & 84.0 & 56.4 & 62.6 & 87.3 & 94.7 & 57.1 \\
& \multicolumn{7}{c}{ Non-IT capital stock per capita } \\
1980 & 82.5 & 44.1 & 25.7 & 38.0 & 63.4 & 38.2 & 99.1 \\
1989 & 92.5 & 51.5 & 32.6 & 44.0 & 70.6 & 54.8 & 110.0 \\
1995 & 94.8 & 53.0 & 36.9 & 48.3 & 79.3 & 64.4 & 120.6 \\
2001 & 101.4 & 57.4 & 44.5 & 54.1 & 87.2 & 75.1 & 127.1 \\
& & \multicolumn{7}{c}{ Non-IT capital quality } & & & \\
1980 & 89.5 & 165.7 & 119.2 & 108.5 & 81.9 & 109.2 & 39.6 \\
1989 & 94.1 & 161.2 & 133.2 & 122.6 & 99.5 & 130.0 & 43.6 \\
1995 & 95.6 & 150.7 & 151.5 & 119.9 & 100.5 & 126.0 & 44.7 \\
2001 & 100.8 & 146.5 & 126.7 & 115.8 & 100.1 & 126.1 & 44.9 \\
\hline
\end{tabular}

Notes: U.S. $=100.0$ in 2000. Canada data begins in 1981. 
Table 11.11

Growth in IT capital input and capital stock per capita and IT capital quality (\%)

\begin{tabular}{lcrrrrrr}
\hline \multirow{2}{*}{ Year } & $\begin{array}{c}\text { United } \\
\text { States }\end{array}$ & Canada & $\begin{array}{c}\text { United } \\
\text { Kingdom }\end{array}$ & France & Germany & Italy & Japan \\
\hline \multicolumn{7}{c}{ IT capital input per capita } \\
$1980-1989$ & 16.09 & 17.66 & 14.43 & 11.66 & 10.71 & 11.44 & 20.19 \\
$1989-1995$ & 11.35 & 17.42 & 10.91 & 7.92 & 8.47 & 8.44 & 10.22 \\
$1995-2001$ & 18.47 & 23.42 & 15.69 & 11.55 & 10.87 & 10.98 & 14.71 \\
$7980-1989$ & 11.47 & 18.88 & 14.98 & 11.46 & 10.43 & 11.72 & 14.32 \\
$1989-1995$ & 8.94 & 16.28 & 11.50 & 9.91 & 9.97 & 9.94 & 9.84 \\
$1995-2001$ & 14.34 & 19.73 & 14.16 & 10.35 & 9.40 & 10.28 & 12.25 \\
& \multicolumn{7}{c}{ IT capital quality } \\
$1980-1989$ & 4.63 & -1.22 & -0.56 & 0.20 & 0.28 & -0.27 & 5.88 \\
$1989-1995$ & 2.41 & 1.14 & -0.58 & -1.99 & -1.50 & -1.49 & 0.38 \\
$1995-2001$ & 4.12 & 3.69 & 1.53 & 1.20 & 1.47 & 0.70 & 2.46 \\
\hline
\end{tabular}

Note: Canada data begins in 1981.

I give growth rates for IT capital input per capita, capital stock per capita, and capital quality in table 11.11 . The G7 nations have exhibited double-digit growth in IT capital input per capita since 1995. Canada was the international leader during this period, with the United States close behind. Japan was the leader in growth of IT capital input during the 1980s, another period of double-digit growth in the G7. However, Japanese IT growth slowed markedly during 1989 to 1995, and Canada gained the lead.

Patterns of growth for IT capital stock per capita are similar to those for IT capital input for the four European countries. Changes in the composition of IT capital stock per capita were important sources of growth of IT capital input per capita for the United States, Canada, and Japan. Information technology capital stock also followed the pattern of IT capital input with substantial growth during the 1980s, followed by a pronounced lull during the period 1989 to 1995 . After 1995, the growth rates of IT capital stock surged in all the G7 countries, but exceeded the rates of the 1980s only for the United States and Canada. Finally, growth rates for IT capital quality reflect the rates at which shorter-lived IT assets are substituted for longer-lived assets.

Japan led in the growth of capital quality during the 1980s, but relinquished its lead to the United States in 1989. Information technology capital quality growth for the United States, Canada, and Japan outstripped that for the four European countries for most of the period 1980 to 2001. Patterns of growth in non-IT capital input per capita, non-IT capital stock per capita, and non-IT capital quality given in table 11.12 largely reflect those for capital as a whole presented in table 11.6.

Table 11.13 and figure 11.1 present the contribution of capital input to 
Table 11.12 Growth in non-IT capital input and capital stock per capita and non-IT capital quality (\%)

\begin{tabular}{lccccccc}
\hline Year & $\begin{array}{c}\text { United } \\
\text { States }\end{array}$ & Canada & $\begin{array}{c}\text { United } \\
\text { Kingdom }\end{array}$ & France & Germany & Italy & Japan \\
\hline \multicolumn{7}{c}{ Non-IT capital input per capita } \\
$1980-1989$ & 1.83 & 1.60 & 3.85 & 2.97 & 3.36 & 5.97 & 2.21 \\
$1989-1995$ & 0.68 & -0.66 & 4.22 & 1.20 & 2.09 & 2.17 & 1.95 \\
$1995-2001$ & 2.00 & 0.85 & 0.15 & 1.30 & 1.52 & 2.57 & 0.96 \\
& \multicolumn{7}{c}{ Non-IT capital stock per capita } \\
$1980-1989$ & 1.27 & 1.94 & 2.62 & 1.61 & 1.20 & 4.03 & 1.16 \\
$1989-1995$ & 0.41 & 0.47 & 2.07 & 1.58 & 1.92 & 2.68 & 1.53 \\
$1995-2001$ & 1.11 & 1.32 & 3.12 & 1.87 & 1.59 & 2.56 & 0.88 \\
& \multicolumn{7}{c}{ Non-IT capital quality } \\
$1980-1989$ & 0.56 & -0.35 & 1.23 & 1.36 & 2.16 & 1.94 & 1.05 \\
$1989-1995$ & 0.27 & -1.13 & 2.15 & -0.38 & 0.17 & -0.51 & 0.42 \\
$1995-2001$ & 0.88 & -0.47 & -2.97 & -0.57 & -0.06 & 0.01 & 0.08 \\
\hline
\end{tabular}

Note: Canada data begins in 1981.

Table 11.13 Contribution of total capital, IT capital and non-IT capital to output growth $(\%)$

\begin{tabular}{lccccccc}
\hline Year & $\begin{array}{c}\text { United } \\
\text { States }\end{array}$ & Canada & $\begin{array}{c}\text { United } \\
\text { Kingdom }\end{array}$ & France & Germany & Italy & Japan \\
\hline & & \multicolumn{7}{c}{ Total capital } \\
$1980-1989$ & 1.53 & 1.71 & 1.80 & 2.12 & 1.44 & 2.55 & 1.49 \\
$1989-1995$ & 1.19 & 0.76 & 1.96 & 1.12 & 1.31 & 1.12 & 1.19 \\
$1995-2001$ & 2.10 & 1.67 & 0.94 & 1.15 & 1.11 & 1.47 & 1.01 \\
& & & IT capital & & & & \\
$1980-1989$ & 0.45 & 0.39 & 0.24 & 0.18 & 0.19 & 0.24 & 0.44 \\
$1989-1995$ & 0.49 & 0.49 & 0.27 & 0.19 & 0.26 & 0.26 & 0.32 \\
$1995-2001$ & 0.99 & 0.86 & 0.76 & 0.42 & 0.46 & 0.49 & 0.58 \\
& & & Non-IT capital & & & \\
$1980-1989$ & 1.08 & 1.32 & 1.56 & 1.94 & 1.25 & 2.31 & 1.05 \\
$1989-1995$ & 0.70 & 0.27 & 1.69 & 0.93 & 1.05 & 0.86 & 0.87 \\
$1995-2001$ & 1.11 & 0.81 & 0.18 & 0.73 & 0.65 & 0.98 & 0.43 \\
\hline
\end{tabular}

Notes: Contribution is growth rate times value share. Canada data begins in 1981 .

economic growth for the G7 nations, divided between IT and non-IT. The powerful surge of IT investment in the United States after 1995 is mirrored in similar jumps in growth rates of the contribution of IT capital through the G7. The contribution of IT capital input was similar during the 1980s and the period 1989 to 1995 for all the G7 nations, despite the dip in rates of economic growth after 1989. Japan is an exception to this general pattern with a contribution of IT capital comparable to that of the United 


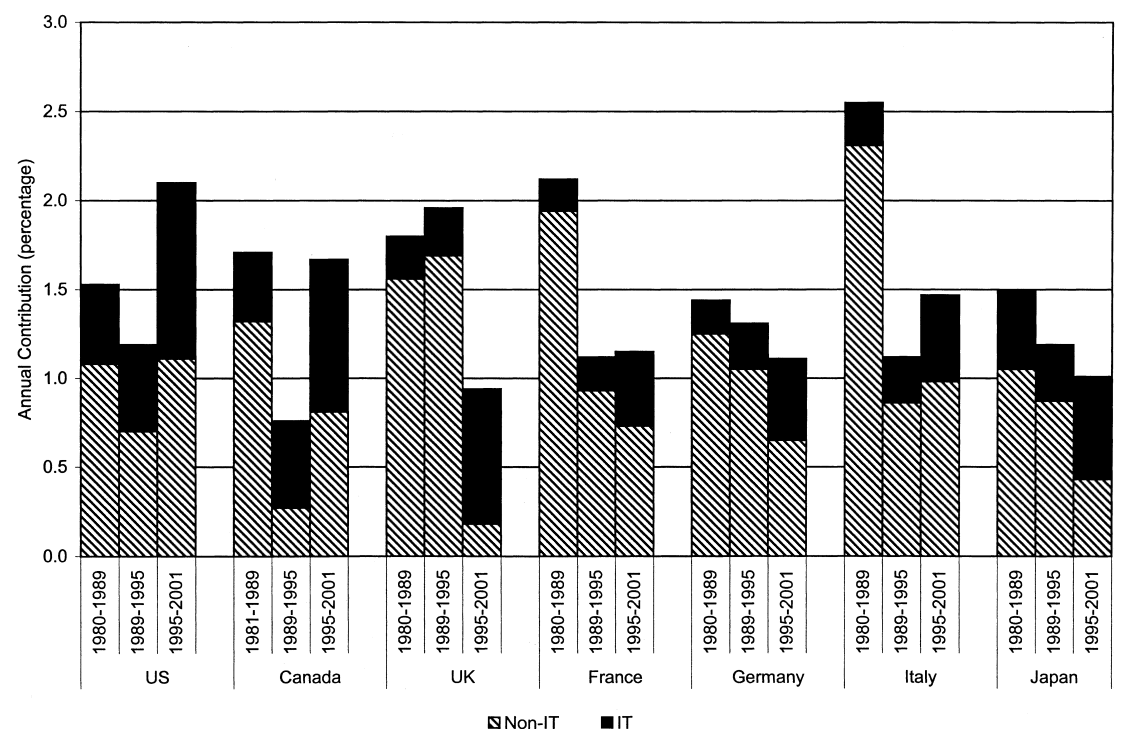

Fig. 11.1 Capital input contribution by country

States during the 1980s, followed by a decline in this contribution from 1989 to 1995, reflecting the sharp downturn in Japanese economic growth.

The contribution of non-IT capital input to economic growth after 1995 exceeded that for IT capital input for four of the G7 nations; the exceptions were Canada, the United Kingdom, and Japan. The United States stands out in the magnitude of the contribution of capital input after 1995. Both IT and non-IT capital input contributed to the U.S. economic resurgence of the last half of the 1990s. Despite the strong performance of IT investment in Japan after 1995, the contribution of capital input declined substantially; the pattern for the United Kingdom is similar.

\subsubsection{The Relative Importance of Investment and Productivity}

Table 11.14 and figure 11.2 present contributions to economic growth from productivity, divided between the IT-producing and non-ITproducing industries. The methodology for this division follows Triplett (1996). The contribution of IT-producing industries was positive throughout the period 1980 to 2001 and jumped substantially after 1995 . Because the level of productivity in Italy was higher in 1980 than in 2001, it is not surprising that the contribution of productivity growth in the non-IT industries was negative throughout the period. Productivity in these industries declined during the period 1989 to 1995 in Canada and Germany as well as Italy. The decline affected Canada, the United Kingdom, France, and Italy from 1989 to 1995 and became very steep in Germany and Italy from 1995 to 2001. 
Table 11.14 Contributions of productivity from IT and non-IT production to output growth (\%)

\begin{tabular}{|c|c|c|c|c|c|c|c|}
\hline Year & $\begin{array}{l}\text { United } \\
\text { States }\end{array}$ & Canada & $\begin{array}{l}\text { United } \\
\text { Kingdom }\end{array}$ & France & Germany & Italy & Japan \\
\hline \multicolumn{8}{|c|}{ Productivity } \\
\hline 1980-1989 & 0.52 & 0.06 & 0.34 & 0.32 & 0.23 & -0.36 & 1.15 \\
\hline 1989-1995 & 0.26 & 0.00 & -0.11 & -0.26 & 1.12 & 0.37 & 1.04 \\
\hline $1995-2001$ & 0.54 & 0.58 & 0.91 & 0.60 & -0.10 & -0.49 & 0.75 \\
\hline \multicolumn{8}{|c|}{ Productivity from IT production } \\
\hline $1980-1989$ & 0.23 & 0.14 & 0.23 & 0.29 & 0.28 & 0.32 & 0.15 \\
\hline 1989-1995 & 0.23 & 0.14 & 0.32 & 0.29 & 0.43 & 0.38 & 0.20 \\
\hline 1995-2001 & 0.48 & 0.17 & 0.82 & 0.56 & 0.65 & 0.68 & 0.46 \\
\hline \multicolumn{8}{|c|}{ Productivity from non-IT production } \\
\hline 1980-1989 & 0.29 & -0.08 & 0.11 & 0.03 & -0.05 & -0.68 & 1.00 \\
\hline 1989-1995 & 0.03 & -0.14 & -0.43 & -0.55 & 0.69 & -0.01 & 0.84 \\
\hline 1995-2001 & 0.06 & 0.41 & 0.09 & 0.04 & -0.75 & -1.17 & 0.29 \\
\hline
\end{tabular}

Note: Canada data begins in 1981.

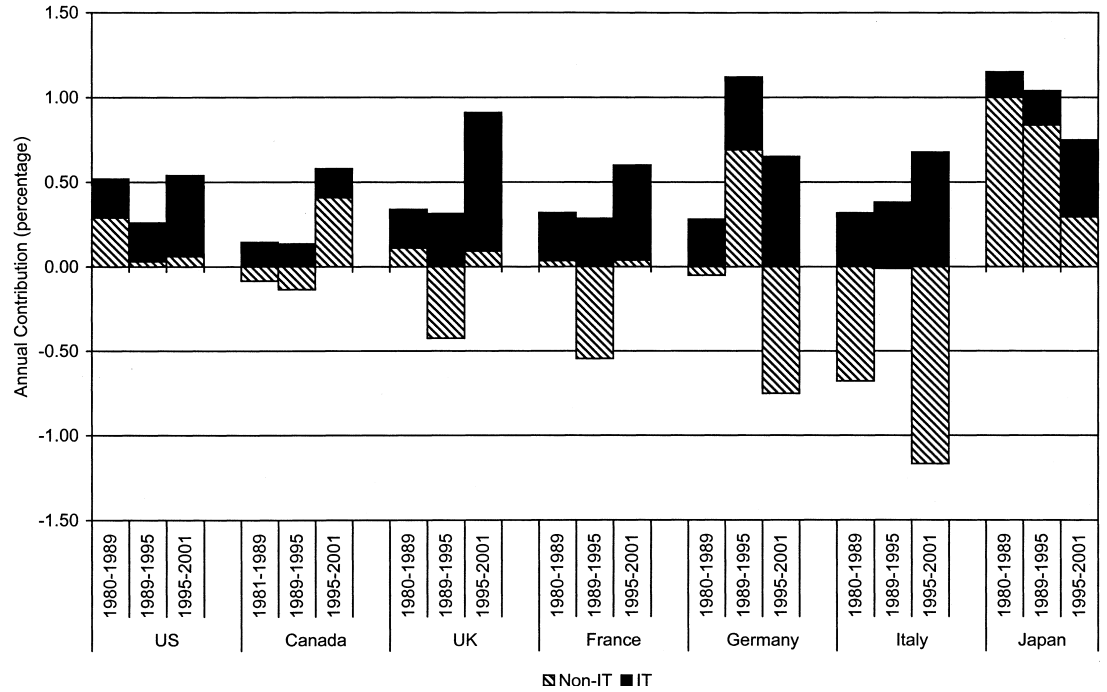

Fig. 11.2 Sources of total factor productivity growth by country

Table 11.15 and figure 11.3 give a comprehensive view of the sources of economic growth for the G7. The contribution of capital input alone exceeds that of productivity for most nations and most time periods. The contribution of non-IT capital input predominates over IT capital input for most countries and most time periods with Canada in 1989 to 1995 and the United Kingdom and Japan after 1995 as exceptions. This can be attributed to the 


\begin{tabular}{|c|c|c|c|c|c|c|c|}
\hline Year & $\begin{array}{l}\text { United } \\
\text { States }\end{array}$ & Canada & $\begin{array}{c}\text { United } \\
\text { Kingdom }\end{array}$ & France & Germany & Italy & Japan \\
\hline \multicolumn{8}{|c|}{ Output } \\
\hline 1980-1989 & 3.38 & 3.10 & 2.69 & 2.38 & 1.99 & 2.51 & 3.83 \\
\hline 1989-1995 & 2.43 & 1.39 & 1.62 & 1.30 & 2.34 & 1.52 & 2.23 \\
\hline 1995-2001 & 3.76 & 3.34 & 2.74 & 2.34 & 1.18 & 1.90 & 1.45 \\
\hline \multicolumn{8}{|c|}{ Labor } \\
\hline 1980-1989 & 1.33 & 1.33 & 0.56 & -0.06 & 0.32 & 0.32 & 1.20 \\
\hline 1989-1995 & 0.98 & 0.62 & -0.24 & 0.44 & -0.09 & 0.03 & 0.00 \\
\hline 1995-2001 & 1.12 & 1.08 & 0.88 & 0.59 & 0.17 & 0.93 & -0.31 \\
\hline \multicolumn{8}{|c|}{ IT capital } \\
\hline 1980-1989 & 0.45 & 0.39 & 0.24 & 0.18 & 0.19 & 0.24 & 0.44 \\
\hline 1989-1995 & 0.49 & 0.49 & 0.27 & 0.19 & 0.26 & 0.26 & 0.32 \\
\hline 1995-2001 & 0.99 & 0.86 & 0.76 & 0.42 & 0.46 & 0.49 & 0.58 \\
\hline \multicolumn{8}{|c|}{ Non-IT capital } \\
\hline 1980-1989 & 1.08 & 1.32 & 1.56 & 1.94 & 1.25 & 2.31 & 1.05 \\
\hline 1989-1995 & 0.70 & 0.27 & 1.69 & 0.93 & 1.05 & 0.86 & 0.87 \\
\hline 1995-2001 & 1.11 & 0.81 & 0.18 & 0.73 & 0.65 & 0.98 & 0.43 \\
\hline \multicolumn{8}{|c|}{ Productivity from IT production } \\
\hline 1980-1989 & 0.23 & 0.14 & 0.23 & 0.29 & 0.28 & 0.32 & 0.15 \\
\hline 1989-1995 & 0.23 & 0.14 & 0.32 & 0.29 & 0.43 & 0.38 & 0.20 \\
\hline $1995-2001$ & 0.48 & 0.17 & 0.82 & 0.56 & 0.65 & 0.68 & 0.46 \\
\hline \multicolumn{8}{|c|}{ Productivity from non-IT production } \\
\hline $1980-1989$ & 0.29 & -0.08 & 0.11 & 0.03 & -0.05 & -0.68 & 1.00 \\
\hline 1989-1995 & 0.03 & -0.14 & -0.43 & -0.55 & 0.69 & -0.01 & 0.84 \\
\hline 1995-2001 & 0.06 & 0.41 & 0.09 & 0.04 & -0.75 & -1.17 & 0.29 \\
\hline
\end{tabular}

Note: Contributions; Canada data begins in 1981.

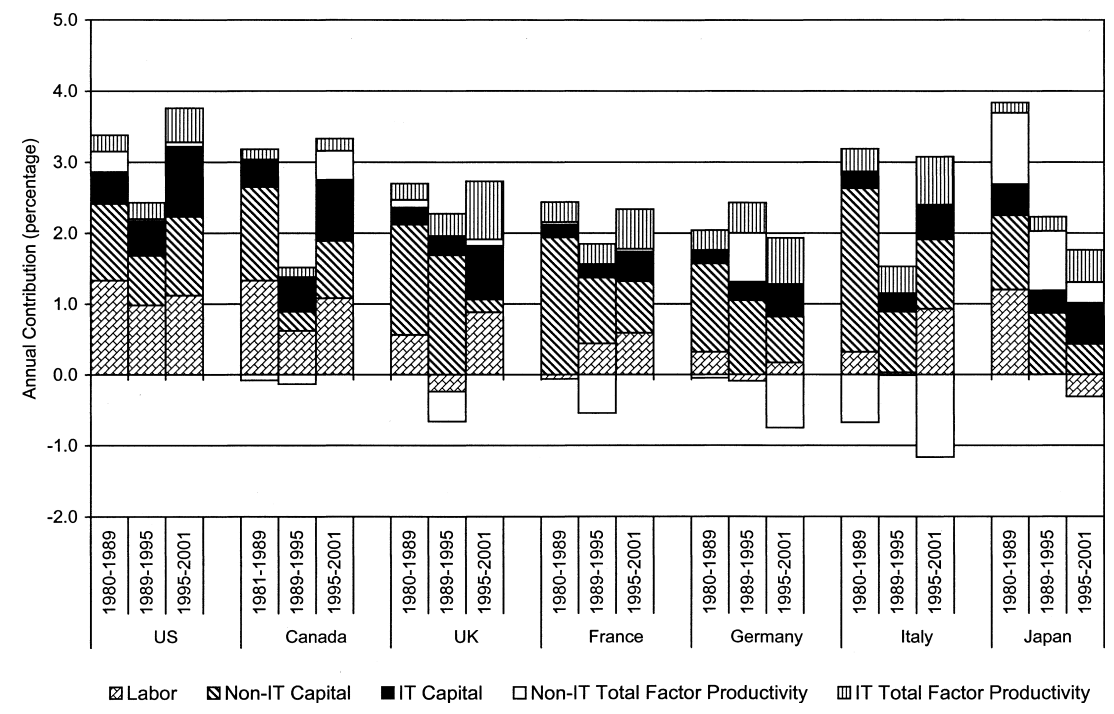

Fig. 11.3 Sources of economic growth by country 
unusual weakness in the growth of aggregate demand in these countries. The contribution of labor input varies considerably among the G7 nations with negative contributions after 1995 in Japan, during the 1980s in France, and during the period 1989 to 1995 in the United Kingdom and Germany.

Finally, table 11.16 and figure 11.4 translate sources of growth into sources of growth in average labor productivity (ALP). Average labor productivity, defined as output per hour worked, must be carefully distinguished from overall productivity, defined as output per unit of both capi-

Table 11.16

Sources of labor productivity growth (\%)

\begin{tabular}{|c|c|c|c|c|c|c|c|}
\hline Year & $\begin{array}{l}\text { United } \\
\text { States }\end{array}$ & Canada & $\begin{array}{c}\text { United } \\
\text { Kingdom }\end{array}$ & France & Germany & Italy & Japan \\
\hline \multicolumn{8}{|c|}{ Output } \\
\hline 1980-1989 & 3.38 & 3.10 & 2.69 & 2.38 & 1.99 & 2.51 & 3.83 \\
\hline 1989-1995 & 2.43 & 1.39 & 1.62 & 1.30 & 2.34 & 1.52 & 2.23 \\
\hline 1995-2001 & 3.76 & 3.34 & 2.74 & 2.34 & 1.18 & 1.90 & 1.45 \\
\hline \multicolumn{8}{|c|}{ Hours } \\
\hline 1980-1989 & 1.79 & 1.87 & 0.82 & -0.66 & 0.11 & 0.15 & 0.95 \\
\hline 1989-1995 & 1.02 & 0.20 & -1.17 & -0.41 & -0.71 & -0.57 & -0.51 \\
\hline $1995-2001$ & 1.53 & 1.93 & 1.03 & 0.91 & -0.11 & 0.99 & -1.14 \\
\hline \multicolumn{8}{|c|}{ Labor productivity } \\
\hline 1980-1989 & 1.58 & 1.23 & 1.87 & 3.04 & 1.88 & 2.36 & 2.89 \\
\hline 1989-1995 & 1.40 & 1.19 & 2.79 & 1.71 & 3.05 & 2.09 & 2.74 \\
\hline 1995-2001 & 2.23 & 1.41 & 1.71 & 1.43 & 1.29 & 0.92 & 2.59 \\
\hline \multicolumn{8}{|c|}{ IT capital deepening } \\
\hline 1980-1989 & 0.40 & 0.35 & 0.22 & 0.19 & 0.19 & 0.23 & 0.42 \\
\hline 1989-1995 & 0.44 & 0.48 & 0.29 & 0.20 & 0.28 & 0.28 & 0.33 \\
\hline 1995-2001 & 0.92 & 0.79 & 0.71 & 0.39 & 0.46 & 0.45 & 0.63 \\
\hline \multicolumn{8}{|c|}{ Non-IT capital deepening } \\
\hline 1980-1989 & 0.37 & 0.42 & 1.20 & 2.29 & 1.20 & 2.25 & 0.69 \\
\hline 1989-1995 & 0.34 & 0.16 & 2.11 & 1.15 & 1.33 & 1.06 & 1.06 \\
\hline 1995-2001 & 0.55 & -0.14 & -0.21 & 0.25 & 0.70 & 0.61 & 0.83 \\
\hline \multicolumn{8}{|c|}{ Labor quality } \\
\hline 1980-1989 & 0.30 & 0.40 & 0.12 & 0.24 & 0.26 & 0.23 & 0.63 \\
\hline 1989-1995 & 0.36 & 0.55 & 0.49 & 0.61 & 0.33 & 0.38 & 0.31 \\
\hline 1995-2001 & 0.23 & 0.18 & 0.30 & 0.19 & 0.23 & 0.35 & 0.38 \\
\hline \multicolumn{8}{|c|}{ Productivity from IT production } \\
\hline 1980-1989 & 0.23 & 0.14 & 0.23 & 0.29 & 0.28 & 0.32 & 0.15 \\
\hline 1989-1995 & 0.23 & 0.14 & 0.32 & 0.29 & 0.43 & 0.38 & 0.20 \\
\hline 1995-2001 & 0.48 & 0.17 & 0.82 & 0.56 & 0.65 & 0.68 & 0.46 \\
\hline \multicolumn{8}{|c|}{ Productivity from non-IT production } \\
\hline 1980-1989 & 0.29 & -0.08 & 0.11 & 0.03 & -0.05 & -0.68 & 1.00 \\
\hline 1989-1995 & 0.03 & -0.14 & -0.43 & -0.55 & 0.69 & -0.01 & 0.84 \\
\hline 1995-2001 & 0.06 & 0.41 & 0.09 & 0.04 & -0.75 & -1.17 & 0.29 \\
\hline
\end{tabular}

Note: Contributions; Canada data begins in 1981. 


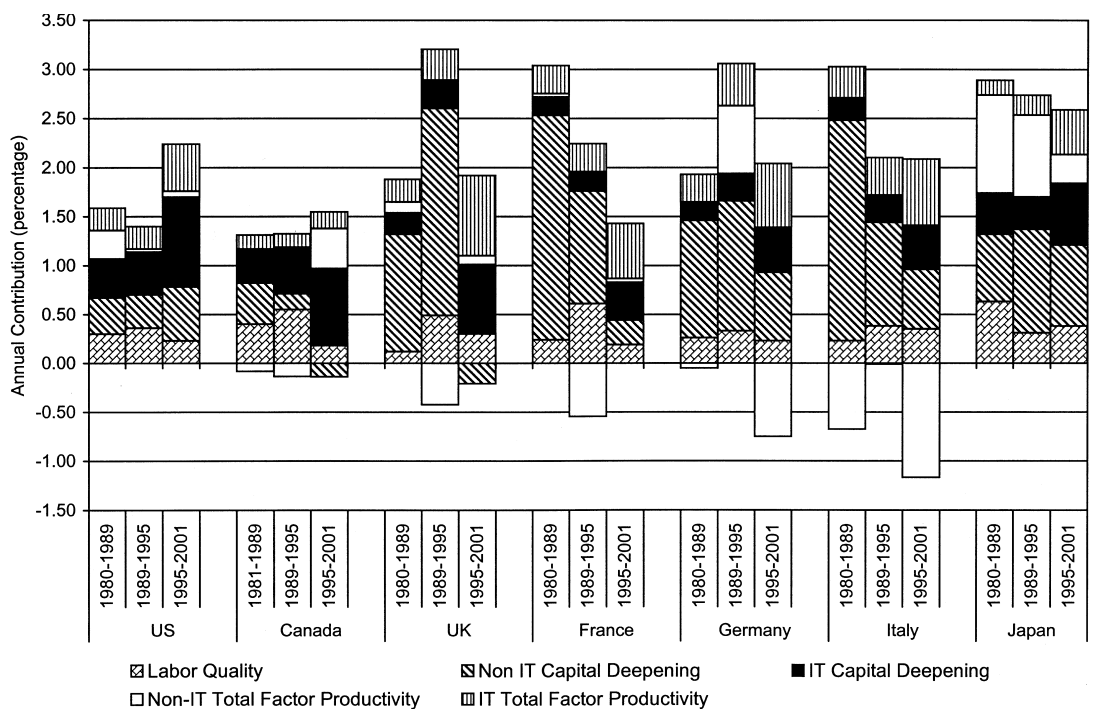

Fig. 11.4 Sources of labor productivity growth by country

tal and labor inputs. Output growth is the sum of growth in hours worked and growth in ALP. Average labor productivity growth depends on the contribution of capital deepening, the contribution of growth in labor quality, and productivity growth.

Capital deepening is the contribution of growth in capital input per hour worked and predominates over productivity as a source of ALP growth for the G7 nations. Information technology capital deepening predominates over non-IT capital deepening in the United States throughout the period 1980-2001 and in Canada after 1989, the United Kingdom and France after 1995. Finally, the contribution of labor quality is positive for all the G7 nations through the period.

\subsection{Alternative Approaches}

Edward Denison's (1967) pathbreaking volume, Why Growth Rates Differ, compared differences in growth rates for national income net of capital consumption per capita for the period 1950 to 1962 with differences of levels in 1960 for eight European countries and the United States. The European countries were characterized by much more rapid growth and a lower level of national income per capita. However, this association did not hold for all comparisons between the individual countries and the United States. Nonetheless, Denison concluded: ${ }^{13}$ 
Aside from short-term aberrations Europe should be able to report higher growth rates, at least in national income per person employed, for a long time. Americans should expect this and not be disturbed by it. $(1967,344)$

Maddison (1987, 1991) constructed estimates of aggregate output, input, and productivity growth for France, Germany, Japan, the Netherlands, and the United Kingdom for the period 1870 to 1987. Maddison (1995) extended estimates for the United States, the United Kingdom, and Japan backward to 1820 and forward to 1992. He defined output as gross of capital consumption throughout the period and constructed constant quality indexes of labor input for the period 1913 to 1984, but not for 1870 to 1913 .

Maddison employed capital stock as a measure of the input of capital, ignoring the changes in the composition of capital stock that are such an important source of growth for the G7 nations. This omission is especially critical in assessing the impact of investment in information technology. Finally, he reduced the growth rate of the price index for investment by 1 percent per year for all countries and all time periods to correct for biases like those identified by Wyckoff (1995).

\subsubsection{Comparisons without Growth Accounts}

Kuznets (1971) provided elaborate comparisons of growth rates for fourteen industrialized countries. Unlike Denison (1967), he did not provide level comparisons. Maddison (1982) filled this lacuna by comparing levels of national product for sixteen countries. These comparisons used estimates of purchasing power parities by Irving Kravis, Alan Heston, and Robert Summers (1978)..$^{14}$

Maddison (1995) extended his long-term estimates of the growth of national product and population to fifty-six countries, covering the period 1820 to 1992. Maddison (2001) updated these estimates to 1998 in his magisterial volume, The World Economy: A Millennial Perspective. He provided estimates for 134 countries, as well as seven regions of the world-Western Europe, Western Offshoots (Australia, Canada, New Zealand, and the United States), Eastern Europe, Former U.S.S.R., Latin America, Asia, and Africa.

Purchasing power parities have been updated by successive versions of the Penn World Table. A complete list of these tables through Mark 5 is given by Summers and Heston (1991). The current version of the Penn World Table is available on the Center for International Comparisons Web site at the University of Pennsylvania (CICUP). This covers 168 countries for the period 1950 to 2000 and represents one of the most significant achievements in economic measurement of the postwar period. ${ }^{15}$

14. For details, see Maddison (1982, 159-68).

15. See Heston, Summers, and Aten (2002). The CICUP Web site is at http://www.pwt.econ .upenn.edu/aboutpwt.html. 


\subsubsection{Convergence}

Data presented by Kuznets (1971), Maddison (2001) and successive versions of the Penn World Table have made it possible to reconsider the issue of convergence raised by Denison (1967). Moses Abramovitz (1986) was the first to take up the challenge by analyzing convergence of output per capita among Maddison's sixteen countries. He found that convergence characterized the postwar period, while there was no tendency toward convergence before 1914 and during the interwar period. Baumol (1986) formalized these results by running a regression of growth rate of GDP per capita over the period 1870 to 1979 on the 1870 level of GDP per capita. ${ }^{16}$

In a highly innovative paper on "Crazy Explanations for the Productivity Slowdown," Paul Romer (1987) derived Baumol's "growth regression" from Solow's (1970) growth model with a Cobb-Douglas production function. Romer's empirical contribution was to extend the growth regressions from Maddison's (1982) sixteen advanced countries to the 115 countries in the Penn World Table (Mark 3). Romer's key finding was an estimate of the elasticity of output with respect to capital close to three-quarters. The share of capital in GNP implied by Solow's model was less than half as great.

Gregory Mankiw, David Romer, and David Weil (1992) defended the traditional framework of Kuznets (1971) and Solow (1970). The empirical part of their study is based on data for ninety-eight countries from the Penn World Table (Mark 4). Like Paul Romer (1987), Mankiw, Romer, and Weil derived a growth regression from the Solow (1970) model; however, they augmented this by allowing for investment in human capital.

The results of Mankiw, Romer, and Weil (1992) provided empirical support for the augmented Solow model. There was clear evidence of the convergence predicted by the model; in addition, the estimated elasticity of output with respect to capital was in line with the share of capital in the value of output. The rate of convergence of output per capita was too slow to be consistent with 1970 version of the Solow model, but supported the augmented version.

\subsubsection{Modeling Productivity Differences}

Finally, Islam (1995) exploited an important feature of the Penn World Table overlooked in prior studies. This panel data set contains benchmark comparisons of levels of the national product at five-year intervals, beginning in 1960. This made it possible to test an assumption maintained in

16. Baumol's (1986) "growth regression" has spawned a vast literature, recently summarized by Steven Durlauf and Danny Quah (1999; Ellen McGrattan and James Schmitz (1999); and Islam (2003). Much of this literature is based on data from successive versions of the Penn World Table. 
growth regressions. These regressions had assumed identical levels of productivity for all countries included in the Penn World Table.

Substantial differences in levels of productivity among countries have been documented by Denison (1967), by my papers with Christensen and Cummings (Christensen, Cummings, and Jorgenson 1981), Dougherty (Dougherty and Jorgenson 1996, 1999), and Yip (Jorgenson and Yip 2000) and in section 11.2. By introducing econometric methods for panel data, Islam (1995) was able to allow for these differences. He corroborated the finding of Mankiw, Romer, and Weil (1992) that the elasticity of output with respect to capital input coincided with the share of capital in the value of output.

In addition, Islam (1995) found that the rate of convergence of output per capita among countries in the Penn World Table substantiated the unaugmented version of the Solow (1970) growth model. In short, "crazy explanations" for the productivity slowdown, like those propounded by Paul Romer $(1987,1994)$, were unnecessary. Moreover, the model did not require augmentation by endogenous investment in human capital, as proposed by Mankiw, Romer, and Weil (1992).

Islam concluded that differences in technology among countries must be included in econometric models of growth rates. This requires econometric techniques for panel data, like those originated by Gary Chamberlain (1984), rather than the regression methods of Baumol (1986), Paul Romer (1987), and Mankiw, Romer, and Weil (1992). Panel data techniques have now superseded regression methods in modeling differences in output per capita.

\subsection{Conclusions}

I conclude that a powerful surge in investment in IT and equipment after 1995 characterizes all of the G7 economies. This accounts for a large portion of the resurgence in U.S. economic growth, but contributes substantially to economic growth in the remaining G7 economies as well. Another significant source of the G7 growth resurgence after 1995 is a jump in productivity growth in IT-producing industries.

For Japan, the dramatic upward leap in the impact of IT investment after 1995 was insufficient to overcome downward pressures from deficient growth of aggregate demand. This manifests itself in declining contributions of non-IT capital and labor inputs. Similar downturns are visible in non-IT capital input in France, Germany, and especially the United Kingdom after 1995.

These findings are based on new data and new methodology for analyzing the sources of economic growth. Internationally harmonized prices for information technology equipment and software are essential for capturing differences among the $\mathrm{G} 7$ nations. Constant quality indexes of capital 
and labor inputs are necessary to incorporate the impacts of investments in IT and human capital.

Exploiting the new data and methodology, I have been able to show that investment in tangible assets is the most important source of economic growth in the G7 nations. The contribution of capital input exceeds that of productivity for all countries for all periods. The relative importance of productivity growth is far less than suggested by the traditional methodology of Kuznets (1971) and Solow (1970), which is now obsolete.

The conclusion from Islam's (1995) research is that the Solow (1970) model is appropriate for modeling the endogenous accumulation of tangible assets. It is unnecessary to endogenize human capital accumulation as well. The transition path to balanced growth equilibrium after a change in policies that affects investment in tangible assets requires decades, while the transition after a change affecting investment in human capital requires as much as a century.

\section{References}

Abramovitz, Moses. 1986. Catching up, forging ahead, and falling behind. Journal of Economic History 46 (2): 385-406.

Baldwin, John R., and Tarek M. Harchaoui. 2002. Productivity growth in Canada2002. Ottawa, Canada: Statistics Canada.

Baumol, William J. 1986. Productivity growth, convergence, and welfare. American Economic Review 76 (5): 1072-85.

Chamberlain, Gary. 1984. Panel data. In Handbook of econometrics. Vol. 2, ed. Zvi Griliches and Michael Intrilagor, 1247-1318. Amsterdam: North-Holland.

Chow, Gregory. 1967. Technological change and the demand for computers. American Economic Review 57 (5): 1117-30.

Christensen, Laurits R., Dianne Cummings, and Dale W. Jorgenson. 1980. Economic growth, 1947-1973: An international comparison. In New developments in productivity measurement and analysis, ed. John W. Kendrick and Beatrice Vaccara, 595-698. Chicago: University of Chicago Press. 16 (1): 61-94.

Colecchia, Alessandra, and Paul Schreyer. 2002. ICT investment and economic growth in the 1990s: Is the United States a unique case? A comparative study of nine OECD countries. Review of Economic Dynamics 5 (2): 408-42.

Court, Andrew T. 1939. Hedonic price indexes with automotive examples. In The dynamics of automobile demand, 99-117. New York: General Motors Corporation.

Denison, Edward F. 1967. Why growth rates differ. Washington, DC: Brookings Institution.

Dougherty, Chrys, and Dale W. Jorgenson. 1996. International comparisons of the sources of economic growth. American Economic Review 86 (2): 25-29.

. 1997. There is no silver bullet: Investment and growth in the G7. National Institute Economic Review 162 (1): 57-74. 
Durlauf, Steven N., and Danny T. Quah. 1999. The new empirics of economic growth. In Handbook of macroeconomics. Vol. 1A, ed. J. B. Taylor and M. Woodford, 235-310. Amsterdam: North-Holland.

Griliches, Zvi. 1961. Hedonic price indexes for automobiles: An econometric analysis of quality change. In Price statistics of the federal government, 137-96. New York: National Bureau of Economic Research.

Heston, Alan, Robert Summers, and Bettina Aten. 2002. Penn World Table version 6.1. Philadelphia: Center for International Comparisons at the University of Pennsylvania (CICUP).

Islam, Nasrul. 1995. Growth empirics. Quarterly Journal of Economics 110 (4): $1127-70$.

2003. What have we learned from the convergence debate? Journal of Economic Surveys 17 (3): 309-62.

Jorgenson, Dale W. 2001. Information technology and the U.S. economy. American Economic Review 91 (1): 1-32.

. 2003. Information technology and the G7 economies. World Economics 4 (4): $139-70$.

2005. Accounting for growth in the information age. In Handbook of economic growth. Vol. 1A, ed. Philippe Aghion and Steven Durlauf, 743-815. Amsterdam: North-Holland.

Jorgenson, Dale W., and Zvi Griliches. 1967. The explanation of productivity change. Review of Economic Studies 34 (99): 249-80.

Jorgenson, Dale W., Mun S. Ho, and Kevin J. Stiroh. 2005. Information technology and the American growth resurgence. Cambridge, MA: MIT Press.

Jorgenson, Dale W., and Kazuyuki Motohashi. 2005. Information technology and the Japanese economy. Journal of the Japanese and International Economies 19 (4): $460-81$.

Jorgenson, Dale W., and Kevin J. Stiroh. 2000. Raising the speed limit: U.S. economic growth in the information age. Brookings Papers on Economic Activity, Issue no. 1:125-211. Washington, DC: Brookings Institution.

Jorgenson, Dale W., and Eric Yip. 2000. Whatever happened to productivity growth? In New developments in productivity analysis, ed. Charles R. Hulten, Edwin R. Dean, and Michael J. Harper, 509-40. Chicago: University of Chicago Press.

Kravis, Irving B., Alan Heston, and Robert Summers. 1978. International comparisons of real product and purchasing power. Baltimore: Johns Hopkins University Press.

Kuznets, Simon. 1971. Economic growth of nations. Cambridge, MA: Harvard University Press.

Maddison, Angus. 1982. Phases of capitalist development. Oxford, UK: Oxford University Press.

- 1987. Growth and slowdown in advanced capitalist economies: Techniques of quantitative assessment. Journal of Economic Literature 25 (2): 649-98. versity Press.

. 1995. Monitoring the world economy. Paris: Organization for Economic Cooperation and Development.

. 2001. The world economy: A millenial perspective. Paris: Organization for Economic Cooperation and Development.

Mankiw, N. Gregory, David Romer, and David Weil. 1992. A contribution to the empirics of economic growth. Quarterly Journal of Economics 107 (2): 407-37.

McGrattan, Ellen, and James Schmitz. 1999. Explaining cross-country income 
differences. In Handbook of macroeconomics, ed. J. B. Taylor and M. Woodford, 669-737. Amsterdam: North-Holland.

Oliner, Stephen D., and Daniel J. Sichel. 20000. The resurgence of growth in the late 1990s: Is information technology the story? Journal of Economic Perspectives 14 (4): 3-22.

Organization for Economic Cooperation and Development. 2002. Purchasing power parities and real expenditures - 1999 benchmark year. Paris: OECD.

Romer, Paul. 1987. Crazy explanations for the productivity slowdown. In NBER macroeconomics annual 1986, ed. Stanley Fischer, 163-201. Cambridge, MA: MIT Press. 8 (1): 3-20.

Schreyer, Paul. 2000. The contribution of information and communication technology to output growth: A study of the G7 countries. OECD Working Paper. Paris: Organization for Economic Cooperation and Development. May 23.

Solow, Robert M. 1970. Growth theory: An exposition. New York: Oxford University Press.

Summers, Robert, and Alan Heston. 1991. The Penn World Table (Mark 5): An expanded set of international comparisons, 1950-1988. Quarterly Journal of Economics 106 (2): 327-68.

Triplett, Jack. 1996. High-tech industry productivity and hedonic price indices. In Industry productivity, 119-42. Paris: Organization for Economic Cooperation and Development.

van Ark, Bart, Johanna Melka, Nanno Mulder, Marcel Timmer, and Gerard Ypma. 2002. ICT investment and growth accounts for the European Union, 19802000. Brussels, Belgium: European Commission.

Wyckoff, Andrew W. 1995. The impact of computer prices on international comparisons of productivity. Economics of Innovation and New Technology 3 (3-4): 277-93. 